\title{
PENERAPAN MODEL PEMBELAJARAN KONTEKSTUAL UNTUK MENINGKATKAN HASIL BELAJAR MATEMATIKA
}

\author{
Panji Setiawan, I Dewa Nyoman Sudana \\ Jurusan PPG PGSD Prajabatan \\ Universitas Pendidikan Ganesha \\ Singaraja, Indonesia \\ e-mail: panjiriflame646@gmail.com, dewanyoman.sudana@undiksha.ac.id
}

\begin{abstract}
Abstrak
Penelitian ini dilatarbelakangi oleh rendahnya hasil belajar matematika siswa kelas 5 SD Negeri 4 Kaliuntu. Rendahnya hasil belajar matematika siswa disebabkan oleh rendahnya pemahaman siswa terhadap materi pelajaran yang disampaikan oleh guru. Dalam penyampaian materi, guru tidak menggunakan model pembelajaran dengan pendekatan saintifik yang menyebabkan ada siswa yang terlihat kurang aktif dalam kegiatan pembelajaran. Adapun tujuan dilaksanakannya penelitian ini adalah untuk meningkatkan hasil belajar matematika siswa kelas 5 SD Negeri 4 Kaliuntu. Penelitian ini merupakan penelitian tindakan kelas yang terdiri dari dua siklus. Tiap siklus mempunyai tahapan diantaranya tahap perencanaan tindakan, tahap pelaksanaan, tahap observasi, dan tahap refleksi. Dalam penelitian ini digunakan model pembelajaran kontekstual. Hasil penelitian menunjukkan bahwa terjadi peningkatan hasil belajar siswa pada tiap siklus. Sebelum dilaksanakan penelitian, nilai ratarata matematika siswa yang diambil dari nilai semester I adalah 67,98. Pada siklus I dapat diketahui bahwa terjadi peningkatan hasil belajar matematika siswa dengan nilai rata-rata adalah 78,42 dan persentase ketuntasan klasikal $92 \%$. Target penelitian pada siklus I masih belum tercapai sehingga penelitian dilanjutkan ke siklus II. Pada pelaksanaan siklus II diperbaiki kekurangan-kekurangan yang ada pada siklus I sehingga nilai rata-rata hasil belajar matematika siswa mengalami peningkatan menjadi 82,94 dengan persentase ketuntasan klasikal $100 \%$. Hal ini menunjukkan bahwa target penelitian telah tercapai pada siklus dua yaitu nila rata-rata hasil belajar siswa berdasarkan PAP masuk dalam kategori tinggi sehingga dapat disimpulkan bahwa penggunaan model pembelajaran kontekstual dapat meningkatkan hasil belajar matematika siswa kelas 5 SD Negeri 4 Kaliuntu Tahun $2017 / 2018$.
\end{abstract}

Kata-kata Kunci : Pembelajaran Kontekstual, Hasil Belajar Matematika

\begin{abstract}
This research was motivated by the low of mathematics learning result in 5th grade students in SD Negeri 4 Kaliuntu. The low of mathematics learning result was caused by the low understanding of the students in the subject materials presented by the teacher. In the delivery of materials, teachers did not use learning models with a scientific approach that caused students to appear less active in learning activities. The purpose of this research was to enhance the result of mathematics learning result in 5th grade students in SD Negeri 4 Kaliuntu. The kind of this research was a classroom action research wich was conducted in two cycles. Each cycle had stages including of action planning, implementation, observation, and reflection. This research used contextual teaching learning model. The results showed that there was an increase in student learning result in each cycle. Before the research was conducted, the average of students'mathematics score that taken from the first semester was 67.98 . In the first cycle could be seen that there was an increase in student learning result with the average score is 78.42 and $92 \%$ classical completeness percentage. The target of research in the first cycle hadn't reached so that the research was continued into second cycle. In the implementation of the second cycle, the deficiencies that existed in the first cycle was fixed so that the average score of students' mathematics learning result increased to 82.94 with $100 \%$ classical completeness percentage. This indicate that the target of the research has been achieved in second cycle. The average of student learning result based on the PAP is in the high category so it can be concluded that the use of contextual teahing learning
\end{abstract}


Jurnal IImiah Pendidikan Profesi Guru Vol. 2 No. 3, Oktober 2019

P-ISSN : 2621-5713, E-ISSN : 2621-5705

model can improve the learning outcomes of 5th grade students of SD Negeri 4 Kaliuntu Year $2017 / 2018$.

Key Word: CTL, Mathematics Learning Result

\section{Pendahuluan}

Undang-Undang Republik Indonesia Nomor 2 Tahun 1989 tentang Sistem Pendidikan Nasional atau yang lebih dikenal dengan sebutan Undang-Undang Sistem Pendidikan Nasional (UUSPN) pasal 1 ayat 1 menyatakan bahwa "Pendidikan adalah usaha sadar untuk menyiapkan siswa melalui kegiatan bimbingan, pengajaran, dan/ atau latihan bagi peranannya di masa yang akan datang". Sejalan dengan pengertian tersebut, tidak dapat diragukan lagi, bahwa sejak anak manusia yang pertama-tama lahir ke dunia, telah ada dilakukan usahausaha pendidikan; manusia telah berusaha mendidik anak-anaknya, kendati pun dengan cara yang sangat sederhana. Demikian pula semenjak manusia saling bergaul, telah ada usahausaha dari orang-orang yang lebih mampu dalam hal-hal tertentu untuk mempengaruhi teman bergaul mereka, untuk kepentingan kemajuan orang-orang yang bersangkutan.

Di Indonesia, pendidikan merupakan salah satu upaya yang dilakukan untuk mencapai tujuan Negara Kesatuan Republik Indonesia yang tertuang dalam teks pembukaan UndangUndang Dasar 1945 yaitu "Mencerdaskan kehidupan bangsa". Hal ini berarti, bahwa pendidikan merupakan bagian yang sangat penting bagi bangsa Indonesia dalam kehidupan baik pada masa sekarang maupun pada masa yang akan datang. Dalam upaya mencerdaskan kehidupan bangsa, pemerintah berupaya meningkatkan kualitas pendidikan dengan cara pembaruan kurikulum, penambahan sumber belajar, peningkatan mutu tenaga pengajar, serta penggunaan model-model pembelajaran yang sesuai dengan kebutuhan siswa.

Dalam pembelajaran di SD, salah satu mata pelajaran yang penting adalah Matematika. Nasution (dalam Subarinah, 2006: 1) menjelaskan istilah matematika berasal dari bahasa Yunani "mathein" atau "manthenein" artinya "mempelajari", namun diduga kata itu ada hubungannya dengan kata Sansekerta "medha" atau "widya" yang artinya "kepandaian", "ketahuan", "intelegensi".

Matematika sangat erat kaitannya dengan kehidupan. Hal ini sejalan dengan pendapat Kline (dalam Alkusaeri, 2013: 4) bahwa "matematika bukanlah pengetahuan yang dapat sempurna karena dirirnya sendiri, tetapi keberadaannya untuk membantu manusia memahami, menguasai permasalahan sosial, ekonomi dan alam". Oleh karena itu, dapat dikatakan matematika berguna bagi tiap sendi-sendi kehidupan manusia.

Beth \& Piaget ( dalam Runtukahu dan Kandou, 2014:28) mengatakan bahwa yang dimaksud dengan matematika adalah pengetahuan yang berkaitan dengan berbagai struktur abstrak dan hubungan struktur-struktur tersebut sehingga terorganisasi dengan baik. Menurut Johnson dan Rising (dalam Karso, 2007: 1.39), bahwa matematika adalah pola berpikir bagaimana mengorganisasikan pembuktian yang logis. Matematika merupakan bahasa yang menggunakan istilah yang didefinisikan dengan cermat, jelas, dan akurat, yang representasinya menggunakan simbol. Matematika adalah pengetahuan struktur yang terorganisasi, sifat-sifat atau teori-teori dibuat secara deduktif berdasarkan kepada unsur yang tidak didefinisikan, yakni telah dibuktikan kebenarannya.

Reys (dalam Karso, 2007: 1.40), mengatakan bahwa matematika adalah telaahan tentang pola dan hubungan, suatu jalan atau pola berpikir, suatu seni, suatu bahasa dan suatu alat. Sedangkan menurut Kline bahwa matematika itu bukan pengetahuan menyendiri yang dapat sempurna karena dirinya sendiri, tetapi keberadaannya untuk membantu manusia memahami, menguasai permasalahan sosial, ekonomi, dan alam. Berdasarkan beberapa pendapat di atas, maka dapat disimpulkan bahwa matematika merupakan suatu ilmu yang mempelajari tentang konsep-konsep logika yang representasinya menggunakan symbol, pola, dan hubungan yang berfungsi untuk membantu manusia memahami, menguasai permasalahan sosial, ekonomi, dan alam. 
Salah satu SD yang memiliki masalah dalam hasil belajar matematika siswanya adalah SDN 4 Kaliuntu. Di kelas 5 SDN 4 Kaliuntu, hasil belajar matematika dapat dikatakan rendah. $\mathrm{Hal}$ ini dapat dilihat dari hasil rekap nilai matematika siswa pada semester 1 . Nilai rata-rata 38 siswa adalah 68,00 yang apabila dikonversi ke tabel penilaian acuan patokan masuk dalam kategori sedang. Bahkan sembilan orang siswa secara individu masuk kategori kurang dan 1 orang siswa tidak mencapai KKM sekolah yaitu 60.00.

Pada tanggal 6 Pebruari 2018, peneliti melaksanakan observasi di SDN 4 Kaliuntu dilanjutkan wawancara pada hari yang sama dengan guru kelas 5 dan guru kelas 4 untuk mengetahui penyebab rendahnya hasil belajar matematika siswa kelas 5 SDN 4 Kaliuntu. Berdasarkan hasil observasi dan wawancara diketahui bahwa penyebab rendahnya hasil belajar yang ada di kelas 5 SDN 4 Kaliuntu adalah rendahnya pemahaman siswa terhadap materi pelajaran yang disampaikan oleh guru. Dalam penyampaian materi, guru tidak menggunakan model pembelajaran dengan pendekatan saintifik yang menyebabkan ada siswa yang terlihat kurang aktif dalam kegiatan pembelajaran. Penggunaan model pembelajaran diperlukan untuk mengaktifkan siswa dalam kegiatan pembelajaran sehingga siswa dapat menkonstruksi dan menemukan sendiri konsep dari materi pelajaran yang disampaikan guru.

Salah satu model pembelajaran yang dapat mengaktifkan siswa adalah model pembelajaran kontekstual. Model pembelajaran ini menghubungkan konsep pelajaran dengan kehidupan siswa. Dalam kegiatan pembelajaran kontekstual, siswa menkonstruksi dan menemukan sendiri konsep atau pengetahuan yang diterima. Pembelajaran kontekstual memiliki tujuh prinsip yang berorientasi pada siswa yaitu konstruktivisme, inkuiri, bertanya, masyarakat belajar (berkelompok), pemodelan, refleksi siswa, dan penilaian autentik.

Lebih lanjut Rusman (2012: 193) menjelaskan prinsip-prinsip tersebut antaranya sebagai berikut., (1) Konstruktivisme merupakan landasan berpikir dalam pembelajaran kontekstual, yaitu bahwa pengetahuan dibangun oleh manusia sedikit demi sedikityang hasilnya diperluas melalui konteks yang terbatas. Pengetahuan bukanlah seperangkat fakta, konsep atau kaidah yang siap untuk diambil dan diingat. Manusia harus membangun pengetahuan itu memberi makna melalui pengalaman yang nyata. Batasan konstruktivisme di atas memberikan penekanan bahwa konsep bukanlah tidak penting sebagai bagian integral dari pengalaman belajar yang harus dimiliki oleh siswa, akan tetapi bagaimana dari setiap konsep atau pengetahuan yang dimiliki siswa itu dapat memberikan pedoman nyata untuk diaktualisasikan dalam kondisi nyata, (2) Menemukan merupakan kegiatan inti dari pembelajara kontekstual, melalui upaya meemukan akan memberikan penegasan bahwa pengetahuan dan keterampilan serta kemampuan-kemampuan lain yang diperlukan bukan merupakan hasil mengingat seperangkat fakta-fakta, tetapi merupakan hasil menemukan sendiri, (3) Unsur lain yang menjadi karakteristik utama pembelajaran kontekstual adalah kemampuan dan kebiassaan bertanya. Pengetahuan yang dimiliki seseorang selalu bermula dari bertanya. Oleh karena itu, bertanya merupakan strategi utam dan pembelajaran kontekstual. Penerapan unsur bertanya dalam pembelajaran kontekstual harus difasilitasi oleh guru, kebiasaan siswa untuk bertanya atau kemampuan guru dalam menggunakan pertanyaan yang baik akan mendorong pada peningkatan kualitas dan produktivitas pembelajaran. Berkembangnya kemampuan dan keinginan untuk bertanya sangat dipengaruhi oleh suasana kegiatan pembelajaran yang dikembangkan oleh guru. Pertanyaan yang diajukan oleh guru atau siswa harus dijadikan alat untuk menggali informai atau sumber yang ada kaitannya dengan kehidupan nyata.dengan kata lain, tugas bagi guru adalah membimbing siswa melalui pertanyaan yang diajukan untuk mencari dan menemukan kaitan antara konsep yang dipelajari dengan kehidupan nyata, (4) Maksud dari masyarakat belajar adalah membiasakan siswa untuk melakukan kerja sama dan memanfaatkan sumber belajar dari teman belajarnya. Seperti yang disarankan pada learning community bahwa hasil belajar diperoleh dari hasil kerja sama dengan orang lain melalui berbagai pengalaman (Sharing). Melalui sharing ini anak dibiasakan utuk saling memberi dan menerima dari teman belajarnya, (5) Guru bukan satu-satunya sumber belajar bagi siswa, karena dengan segala kelebihan dan keterbatasan yang dimiliki oleh guru akan mengalami hambatan untuk memberikan pelayanan sesuai dengan kebutuhan siswa yang heterogen. Oleh 
karena itu, tahap pembuatan model dapat dijadikan alternatif untuk mengembangkan pembelajaran dan mengatasi keterbatasan yang dimiliki oleh para guru, (6) Refleksi adalah cara berpikir tentang apa yang baru terjadi atau baru dipelajari.dengan kata lain refleksi adalah berpikir ke belakang tentang apa-apa yang sudah dilakukan di masa lalu, siswa mengendapkan apa yang sudah dipelajarinya sebagai struktur pengetahuan yang baru yang merupakan pengayaan atau revisi dari pengetahuan sebelumnya.pda saat refleksi, siswa diberi kesempatan utuk mencerna, menimbang, membandingkan, menghayati, dan melakukan diskusi dengan dirinya sendiri. (7) Tahap terakhir dari pembelajaran kontekstual adalah melakukan penilaian. Penilaian sebagai bagian integral dari pembelajaran memiliki fungsi yang amat menentukan untuk mendapatkan informasi kualitas dan hasil pembelajarn kontekstual. Dengan terkumpulnya berbagai data dan informasi yang lengkap sebagai perwujudan dari penerapan penilain, maka akan semakin akurat pula pemahaman guru terhadap proses dan hasil pengalaman belajar siswa.

Pembelajaran kontekstual merupakan konsep belajar yang dapat membantu guru mengaitkan antara materi yang diajarkannya dengan situasi dunia nyata siswa dan mendorong siswa membuat hubungan antar pengetahuan yang dimilikinya dengan penerapannya dalam kehidupan mereka sebagai anggota keluarga dan masyarakat (Nurhadi, 2002). Pembelajaran seperti ini serupa dengan pembelajaran berbasis fenomena seperti yang dilakukan Dewantara, dkk. (2009) dengan menggunakan teks fenomena untuk membangkitkan motivasi mahasiswa dalam belajar.

Dengan pembelajaran kontekstual proses pembelajaran diharapkan berlangsung alamiah dalam bentuk kegiatan siswa untuk bekerja dan mengalami, bukan transfer pengetahuan dari guru ke siswa. Strategi pembelajaran lebih dipentingkan dari pada hasil. Dalam konteks itu siswa perlu mengerti apa makna belajar, apa manfaatnya, mereka dalam status apa dan bagaimana cara mencapainya. Mereka akan menyadari bahwa yang mereka pelajari berguna bagi hidupnya. Dengan demikian mereka mempelajari sesuatu yang bermanfaat bagi dirinya dan berupaya menggapainya. Dalam upaya itu, mereka memerlukan guru sebagai pengarah dan pembimbing. Untuk menciptakan kondisi tersebut strategi belajar yang tidak mengharuskan siswa menghafal fakta-fakta, tetapi sebuah strategi yang mendorong siswa mengkontruksi pengetahuan dibenak mereka sendiri.

Johnson (dalam Rusman, 2012: 189) menjelaskan bahwa Pembelajaran kontekstual memungkinkan siswa mengubungkan isi mata pelajaran akademik dengan konteks kehidupan sehari-hari untuk menemukan makna. Pembelajaran kontekstual memperluas konteks priibadi siswa lebih lanjut melalui pemberian pengalaman segar yang akan merangsang otak guna menjalin hubungan baru utuk menemukan makna yang baru.

Shoimin (2014) menjabarkan beberapa kelebihan pembelajaran kontekstual di antaranya sebagai berikut, (1) Pembelajaran kontekstual dapat meningkatkan aktivitas berpikir siswa seara penuh baik fisik maupun mental, (2) Pembelajara kontekstual dapat menjadikan siswa belajar bukan dengan menghafal, melainkan proses berpengalaman dalam kehiduan nyata, (3) Kelas dalam kontekstual bukan tempat untuk memperoleh informasi, melainkan sebagai tempat untuk menguji data hasil temuan mereka di lapangan, (4) Materi pelajaran dikonstruksi oleh siswa sendiri.

Berdassarkan uraian di atas, penelitian ini bertujuan untuk mengetahui peningkatkan hasil belajar Matematika siswa kelas 5 SDN 4 Kaliuntu melalui penerapan model pembelajaran kontekstual Tahun Pelajaran 2017/2018.

Peneliti menganggap model pembelajaran kontekstual adalah model pembelajaran yang cocok untuk menyelesaikan masalah hasil belajar matematika di SDN 4 Kaliuntu. Oleh karena itu, peneliti ingin mengadakan penelitian tindakan kelas dengan cara menerapkan model pembelajaran kontekstual untuk meningkatkan hasil belajar matematika siswa kelas 5 di SDN 4 Kaliuntu.

\section{Metode}


Penelitian ini dilaksanakan dengan model siklus dengan langkah-langkah dalam tiap siklus diantaranya; tahap perencanaan tindakan, pelaksanaan, pengamatan/ observasi, dan refleksi yang kemudian apabila target penelitian belum tercapai pada siklus pertama maka penelitian akan dilanjutkan ke siklus selanjutnya ikuti dengan perencanaan ulang pada siklus kedua, dan seterusnya. Berikut gambar alur PTK.

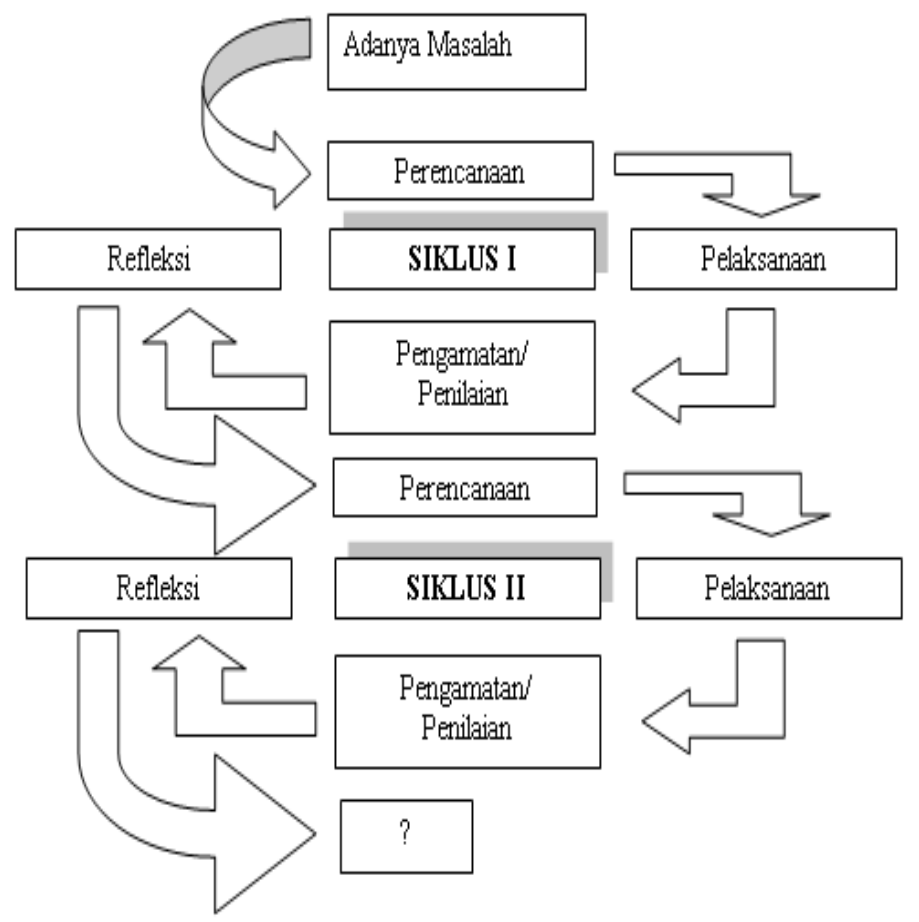

Gambar 3.1 Siklus Kegiatan PTK (Arikunto 2010: 137)

Tahap pertama dalam penelitian ini adalah perencanaan. Adapun kegiatan yang dilakukan dalam tahap ini adalah sebagai berikut, (1) Merencanakan pembelajaran bersama guru umtuk mengetahui hal-hal yang perlu diperhatikan sebelum membuat perangkat pembelajaran, (2) Menyesuaikan materi pelajaran dengan model pembelajaran kontekstual, (3) Menyusun RPP dengan model pembelajaran kontekstual, (4) Menyiapkan media pembelajaran yang diperlukan, (5) Membuat instrumen pengamatan kinerja guru dalam menerapkan model pembelajaran kontekstual, (6) Membuat instrumen penilaian aktivitas siswa, (7) Membuat soal evaluasi untuk mengetahui hasil belajar siswa, (8) Membahas kembali perangkat pembelajaran dan instrumen observasi yang telah dibuat bersama guru.

Kegiatan selanjutnya adalah kegiatan pelaksanaan model pembelajaran kontekstual dalam kegiatan pembelajaran. Guru menanamkan ketujuh prinsip pembelajaran kontekstual dalam skenario pembelajaran.

Observasi atau pengamatan adalah kegiatan yang dilakukan untuk mengumpulkan data berupa data kualitatif. Dalam penelitian ini observasi dilaksanakan untuk mengamati cara mengajar guru serta kegiatan belajar siswa selama penerapan model pembelajaran kontekstual.

Penilaian hasil belajar berupa tes tulis/ evaluasi yang bertujuan untuk mengetahui hasil belajar siswa. Sehingga dapat diketahuai peningkatan hasil belajar siswa setelah diterapkannya model pembelajaran kontekstual.

Pada tahap refleksi, peneliti melakukakan analisis data hasil observasi dan hasil evaluasi. Selanjutnya pada tahap ini peneliti mengkaji, melihat, dan mempertimbangkan hasil-hasil atau dampak dari tindakan untuk selanjutnya dijadikan dasar dalam menentukan tindakan selanjutnya. Apabila pada siklus pertama target penelitian belum tercapai, maka penelitian 
akan dilanjutkan ke siklus selanjutnya dengan menggunakan hasil refleksi sebagai acuan dalam memperbaiki kekurangan-kekurangan pada siklus sebelumnya.

Penelitian ini dilaksanakan di kelas V SDN 4 Kaliuntu Kelurahan Kaliuntu Kecamatan Buleleng pada tanggal 3 sampai 17 April 2018. Pelaksanaan kegiatan tiap siklus penelitian ini dialokasikan dua kali pertemuan. Subjek penelitian ini adalah siswa kelas 5 SDN 4 Kaliuntu yang berjumlah 38 orang, terdiri dari 14 laki-laki dan 24 perempuan. Objek penelitian ini adalah hasil belajar matematika dari asoek kognitif siswa kelas V SD Negeri 4 kaliuntu.

Dalam penelitian ini terdapat dua variable yaitu hasil belajar matematika sebagai variabel terikat dan model pembelajaran kontekstual sebagai variabel bebas. Hasil belajar matematika siswa adalah perubahan yang terjadi dari segi kognitif, afektif, dan psikomotorik dalam mata pelajaran matematika yang dinyatakan dalam bentuk nilai, skor atau catatan setelah dilakukannya penilaian. Dalam Penelitian ini, hasil belajar yang dimaksud adalah nilai mata pelajaran matematika yang didapat siswa kelas 5 SDN 4 Kaliuntu setelah diadakannya evaluasi. Model pembelajaran kontekstual adalah konsep belajar yang membantu guru mengkaitkan antara materi yang diajarkanya dengan situasi dunia nyata siswa dan mendorong siswa membuat hubungan antara pengetahuan yang dimilikinya dengan penerapan dalam kehidupan sehari-hari. Siswa diajak aktif menkonstruksi dan menemukan sendiri konsep yang dipelajari.

Metode pengumpulan data yang digunakan dalam penelitian ini adalah bservasi dan tes tulis. Observasi atau pengamatan bertujuan untuk menilai cara mengajar guru dalam menerapkan model pembelajaran kontekstual serta mengamati kegiatan belajar siswa selama penerapan model pembelajaran kontekstual dengan menggunakan lembar observasi yang telah disiapkan sebelumnya. Sedangkan tes tulis berupa pilihan ganda yang akan dilaksanakan tiap akhir siklus untuk mengetahui peningkatan hasil belajar siswa setelah diterapkannya model pembelajaran kontekstual.

Analisis data dalam penelitian ini menggunakan teknik analisis deskriptif kualitatif dan kuantitatif. Analisis data secara kualitatif digunakan untuk menganalisis data hasil observasi. Sedangkan analisis data deskriptif kuantitatif digunakan untuk menganalisa data kuantitatif, seperti hasil tes.

Menghitung nilai rata-rata siswa dapat dilakukan dengan menggunakan rumus:

$$
\begin{array}{ll}
X=\frac{\sum X}{N} & \text { (Sudjana, 2012: 109) } \\
X & =\text { rata-rata } \\
\sum_{N} X \quad=\text { jumlah seluruh skor } \\
\quad=\text { banyaknya subjek }
\end{array}
$$

Tabel 3.1 Pedoman Konversi PAP Skala Lima Tentang Hasil Belajar (Sumber, Agung, 2016: 146)

\begin{tabular}{cc}
\hline Persentase & Kriteria \\
\hline $90-100$ & Sangat Tinggi \\
\hline $80-89$ & Tinggi \\
\hline $65-79$ & Sedang \\
\hline $40-64$ & Rendah \\
\hline $0-39$ & Sangat Rendah \\
\hline
\end{tabular}

Menghitung nilai akhir data hasil observasi aktivitas siswa dan aktivitas guru dapat dihitung dengan rumus:

$$
\begin{aligned}
& N A=\frac{S P}{S M} \times 100 \quad(\text { Kunandar, 2013) } \\
& \text { NA }=\text { Nilai Akhir }
\end{aligned}
$$


$\mathrm{SA} \quad=$ Skor Perolehan

$\mathrm{SM}=$ Skor Maksimal

Menghitung Mean Ideal (Mi) dan Standar Deviasi Ideal (SDi)

$$
\begin{array}{ll}
M i=\frac{1}{2} \times(\text { skor max }+ \text { skor min }) & (\text { Nurkencana dan Sunartana, 1990) } \\
S D i=\frac{1}{6} \times(\text { skor max }- \text { skor min }) & (\text { Nurkencana dan Sunartana, 1990) }
\end{array}
$$

Tabel 3.2 Pedoman Penentuan Kriteria Aktivitas Siswa (Nurkencana dan Sunarta, 1990)

\begin{tabular}{lll}
\hline \multicolumn{1}{c}{ Interval } & \multicolumn{1}{c}{ Skor } & \multicolumn{1}{c}{ Kategori } \\
\hline $\mathrm{Mi}+1,5 \mathrm{SDi}<\mathrm{N}$ & $75<\mathrm{G}$ & Sangat baik \\
$\mathrm{Mi}<\mathrm{N} \leq \mathrm{Mi}+1,5 \mathrm{SDi}$ & $50<\mathrm{G} \leq 75$ & Baik \\
$\mathrm{Mi}-1,5 \mathrm{SDi}<\mathrm{N} \leq \mathrm{Mi}$ & $25<\mathrm{G} \leq 50$ & Kurang baik \\
$\mathrm{N} \leq \mathrm{Mi}-1,5 \mathrm{Sdi}$ & $\mathrm{G} \leq 25$ & Buruk \\
\hline
\end{tabular}

$\mathrm{N}=$ rata-rata skor aktivitas siswa.

Tabel 3.3 Pedoman Penentuan Kriteria Aktivitas Guru (Nurkencana dan Sunarta, 1990)

\begin{tabular}{cll}
\multicolumn{1}{c}{ Interval } & \multicolumn{1}{c}{ Skor } & \multicolumn{1}{c}{ Kategori } \\
\hline $\mathrm{Mi}+1,5 \mathrm{SDi}<\mathrm{G}$ & $75<\mathrm{G}$ & Sangat baik \\
$\mathrm{Mi}<\mathrm{G} \leq \mathrm{Mi}+1,5 \mathrm{SDi}$ & $50<\mathrm{G} \leq 75$ & Baik \\
$\mathrm{Mi}-1,5 \mathrm{SDi}<\mathrm{G} \leq \mathrm{Mi}$ & $25<\mathrm{G} \leq 50$ & Kurang baik \\
$\mathrm{G} \leq \mathrm{Mi}-1,5 \mathrm{SDi}$ & $\mathrm{G} \leq 25$ & Buruk \\
\hline
\end{tabular}

$\mathrm{G}=$ rata-rata skor aktivitas guru.

\section{Pembahasan}

Penelitian tindakan kelas ini dilaksanakan dengan tujuan meningkatkan hasil belajara matematika siswa SDN 4 kaliuntu. Dalam penelitian ini digunakan model pembelajaran kontekstual yang berorientasi pada siswa. Kegiatan penelitian ini dilaksanakan selama dua siklus. Kegiatan pembelajaran disertai evaluasi pembelajaran tiap siklus mempunyai alokasi waktu enam jam pelajaran yang terbagi menjadi dua pertemuan.

Siklus pertama terdiri dari beberapa tahap yaitu tahap perencanaan tindakan, pelaksanaan, pengamatan/ observasi, dan refleksi. Berdasarkan hasil observasi aktivitas belajar siswa pada siklus I diperoleh jumlah skor rata-rata 71 dari nilai maksimal 100 yang masuk dalam kategori baik, sedangkan hasil observasi aktivitas guru diperoleh rata-rata skor 72 dari nilai maksimal 80 yang masuk dalam kategori baik.

Pada siklus I tedapat beberapa kekurangan yang perlu diperbaiki dalam kegiatan pembelajaran khususnya kekurangan dari segi keaktifan dan kedisiplinan siswa. Masih banyak siswa yag terlihat kurang aktif dalam kegiatan pembelajaran baik secara individu maupun kelompok. Hal ini disebabkan karena guru kurang mampu memberikan motivasi bagi siswa. Oleh karena itu guru harus mampu memberikan motivasi belajar bagi siswa serta mengoptimalkan penggunaan model pembelajaran kontekstual untuk menigkatkan keaktifan siswa dalam proses pembelajaran. Selain itu, guru harus mampu memberikan bimbingan dan arahan bagi setiap siswa yang memiliki masalah kedisiplinan dan motivasi belajara yang rendah. 
Setelah dilaksanakan evaluasi pembelajaran pada siklus I, dapat diketahui bahwa nilai rata-rata hasil belajar siswa adalah 78,42, dimana 35 siswa tuntas dengan ketuntasan klasikal $92 \%$. Dari data tersebut, dapat diketahui bahwa nilai rata-rata hasil belajar siswa belum masuk kategori tinggi atau di atas 80 sehingga dapat disimpulkan bahwa target pada siklus I belum tercapai. Peneliti ingin meningkatkan nilai rata-rata hasil belajar siswa, maka dari itu peneliti melanjutkan penelitian ke siklus II.

Tahapan penelitian pada siklus II sama dengan siklus pertama, akan tetapi dalam kegiatan pembelajarannya dilakukan beberapa perbaikan berdasarkan kekurangan pada siklus pertama. Dalam memberikan motivasi, guru mengaitkan materi pelajaran dengan kehidupan serta menjelaskan akibat dan manfaat dari materi pelajaran dalam kehidupan sehari-hari siswa. Selain itu guru juga memberikan reward berupa bintang bagi siswa yang aktif atau berkelakuan baik. Hal ini membuat siswa terlihat lebih antusias dalam kegiatan belajar. Masalah pengendalian kelas telah mampu diatasi oleh guru dengan cara membuat aturan diskusi serta memberikan tambahan poin bagi siswa yang disiplin dan memberikan hukuman berupa pengurangan poin/ bintang bagi siswa yang tidak disiplin.

Pada siklus kedua terjadi perubahan kearah yang lebih baik dari segi aktivitas dan hasil belajar siswa. Skor rata-rata aktivitas belajar siswa dan aktivitas mengajar guru mengalami peningkatan. Skor aktivitas siswa adalah 88 yang masuk kategori aktif, sedangkan skor aktivitas guru adalah 84 yang masuk kategori sangat baik. Rata-rata hasil belajar siswa juga mengalami peningkatan menjadi 82,94. Dari 38 siswa, seluruhnya dinyatakan tuntas sehingga persentase ketuntasan pada siklus kedua menjadi $100 \%$.

Berdasarkan data pada siklus II, dapat diketahui bahwa target nilai rata-rata hasil belajar siswa telah tercapai yaitu 82,94, masuk dalam kategori tinggi (lebih dari 80). Berikut rincian data hasil penilaian aktivitas guru dalam kegiatan pembelajaran, dan hasil belajar siswa pada siklus I dan siklus II yang dijabarkan dalam tabel di bawah ini.

Tabel 4.7 Data Rekapitulasi Pelaksanaan Siklus I dan Siklus II

\begin{tabular}{ccccccc}
\hline \multirow{2}{*}{ Siklus } & \multicolumn{2}{c}{ Aktivitas Siswa } & \multicolumn{2}{c}{ Aktivitas Guru } & \multicolumn{2}{c}{ Hasil Belajar } \\
\cline { 2 - 7 } & $\begin{array}{c}\text { Rata- } \\
\text { rata }\end{array}$ & $\begin{array}{c}\text { Kategor } \\
\mathbf{i}\end{array}$ & $\begin{array}{c}\text { Rata- } \\
\text { rata }\end{array}$ & Kategori & $\begin{array}{c}\text { Rata- } \\
\text { rata }\end{array}$ & $\begin{array}{c}\text { Ketuntasan } \\
\text { Klasikal }\end{array}$ \\
\hline 1 & 71 & Baik & 72 & Baik & 78,42 & $92 \%$ \\
\hline 2 & 88 & $\begin{array}{c}\text { Sangat } \\
\text { Baik }\end{array}$ & 84 & $\begin{array}{c}\text { Sangat } \\
\text { Baik }\end{array}$ & 82,94 & $100 \%$ \\
\hline
\end{tabular}

Dari data di atas, dapat diketahui bahwa indikator keberhasilan penelitian yaitu nilai ratarata seluruh siswa masuk kategori tinggi atau lebih dari 80 telah tercapai pada siklus kedua.

\section{Simpulan dan Saran}

Berdasarkan hasil penelitian yang telah dilaksanakan, dapat disimpulkan bahwa penerapan model pembelajaran kontekstual dapat meningkatakan hasil belajar matematika siswa kelas 5 SDN 4 Kaliuntu.

Pada siklus pertama hasil belajar matematika siswa 78,42 dengan persentase ketuntasan klasikal $92 \%$ yang menunjukkan bahwa target penelitian masih belum tercapai. Pada siklus dua terjadi peningkatan hasil belajar matematika siswa menjadi 82,94 dengan persentase ketuntasan klasikal $100 \%$ yang menunjukkan bahwa seluruh target penelitian telah tercapai pada siklus kedua.

Berdasarkan hasil penelitian yang telah dilaksanakan, peneliti akan menyampaikan beberapa saran sebagai berikut, (1) Guru diharapakan mampu menggunakan model 
pembelajaran kontekstual secara optimal dan tidak hanya menjadikan model pembelajaran kontekstual sebagai alternatif dalam kegiatan pembelajaran, namun menjadikan model pembelajaran kontekstual sebagai pilihan utama dalam melaksanakan kegiatan belajar mengajar, (2) diharapkan bagi kepala sekolah untuk dapat menyediakan sarana dan prasarana yang memadai dalam kegiatan belajar mengajar khususnya dalam penerapan model pembelajaran kontekstual yang memerlukan beraneka ragam media pembelajaran, (3) Diharapkan bagi peneliti lain atau mahasiswa yang ingin melaksanakan penelitian berkaitan dengan model pembelajaran kontekstual untuk mencoba menerapkannya pada materi atau mata pelajaran lain demi meningkatnya hasil belajar siswa.

\section{Daftar Pustaka}

Agung, Anak Agung Gede. 2016. Statiska Dasar untuk Pendidikan. Yogyakarta: Deepublish

Anonim. Undang-Undang No. 2 Tahun 1989 tentang Sistem Pendidikan Nasional. Jakarta: Sekretariat Negara.

Anonim. Undang-Undang Dasar Tahun 1945. Jakarta: Sekretariat Negara.

Alkusaeri. 2013. Pengembangan Program Pembelajaran Matematika. Banjarnegara: Yazido Press.

Aqib, Zainal. 2013.Model-Model Media, dan Strategi Pembelajaran Kontekstual (Inovatif). Bandung: Yrama Widya.

Arikunto, Suharsimi. 2010. Prosedur Penelitian Suatu Pendekatan Praktik. Jakarta: Rineka Cipta.

Depdiknas. 2005. Kamus Besar Bahasa Indonesia (KBBI). Balai Pustaka. Jakarta.Karso,dkk. 2007. Pendidikan Matematika. Banten. Universitas Terbuka.

Dewantara, I. P. M., Suandi, I. N., Rasna, I. W., \& Putrayasa, I. B. (2019). Cultivating Students' Interest and Positive Attitudes towards Indonesian Language through PhenomenonTextBased Information Literacy Learning. International Journal of Instruction, 12(2), 147-162. https://doi.org/10.29333/iji.2019.12210a

Erci, Sarjan N. Husain dan Lestari MP Alibasyah. 2014. Meningkatkan Hasil Belajar Siswa dalam Pembelajaran Ipa Melalui Pendekatan CTL di Kelas V SD Inpres 03 Terpencil Baina'a. Palu: Jurnal Kreatif Tadulako Online Vol. 4 No. 6.

Glynn, Shawn dan Linda K. Winter. 2004. Contextual Teaching and Learning of Science in Elementary Schools. Western Illinois University: Journal of Elementary Science Education, Vol. 16, No. 2 (Fall 2004), pp. 51-63.

Komalasari, Kokom. 2010. Pembelajaran Kontekstual: Konsep dan Aplikasi. Refika Aditama. Bandung.

Kunandar. 2013. Penilaian Autentik (Penilaian Hasil Belajar Peserta Didik Berdasarkan Kurikulum 2013). Jakarta: PT Rajagrafindo Persada.

Mikarsa, Hera L., dkk. 2008. Pendidikan Anak di SD. Jakarta: Universitas Terbuka.

Nurhadi. 2002. Pendekatan Kontekstual (Contextual Teaching and Learning). Malang : Universitas Negeri Malang. 
Nurkencana, Wayan dan Sunartana, 1990. Evaluasi Hasil Belajar. Surabaya: Usaha Nasional.

Rusman. 2012. Model-model Pembelajaran. Jakarta: PT Rajagrafindo Persada.

Runtukahu, Tombokan dan Selpius Kandou. 2014. Pembelajaran Matematika Dasar bagi Anak Berkesulitan Belajar. Yogyakarta: Arruzz Media.

Sapriati, A. dkk. 2009. Pembelajaran IPA di SD.Jakarta: Universitas Terbuka.

Shoimin, Aris. 2014. 68 Model Pembelajaran Inovatif dalam Kurikulum 2013. Yogyakarta: Arruz Media.

Slameto. 2010. Belajar dan Faktor-faktor yang Mempengaruhinya. Jakarta: Rineka Cipta.

Subarinah, Sri. 2006. Inovasi Pembelajaran Matematika di Sekolah Dasar. Jakarta: Departemen Pendidikan Nasional.

Sudjana, Nana. 2012. Penilaian Hasil Proses Belajar Mengajar. Bandung: PT Remaja Rosdakarya.

Suparman, Lalu, A.A.I.Ngurah Marhaeni dan Nyoman Dantes. 2013. The Effect Of Contextual Teaching And Learning Approach And Achievement Motivation Upon Students' Writing Competency For The Tenth Grade Students Of SMAN 1 Keruak In The Academic Year 2012-2013. Singaraja: e-Journal Program Pascasarjana Universitas Pendidikan Ganesha Program Studi Pendidikan Bahasa Inggris. Volume 1.

Trianto. 2010. Mendesain Model Pembelajaran Inovatif-Progresif. Jakarta: Kencana Prenada Media Group. .2011. Penelitian Tindakan Kelas. Jakarta: Kencana Prenada Media Group. 